Carmen Moreno Adán, Raquel Peña López, Oriol Domínguez Martínez

\title{
Restoration of the historic libraries of Chinguetti, Mauritania
}

\author{
Restauración de las bibliotecas históricas de \\ Chinguetti, Mauritania
}

Restauração das bibliotecas históricas de Chinguetti,
Mauritânia

\begin{abstract}
Resumen $\mid$ Resumo
The ancient ksar of Chinguetti was named a UNESCO World Heritage Site in 1996. It is located in West Africa, on one of the most important caravan trading routes, in use from the eighth century until the beginning of the twentieth century. The trans-Sahara traffic - mainly based on products such as salt, gold and ivory - also fostered cultural development along the route. As commercial, cultural and religious contacts were established over the centuries, manuscripts were constantly being written, copied, carried, bought and sold. In 2000, following a failed attempt to build a museum to house Chinguetti's most important manuscripts, the Spanish Agency for International Development Cooperation (AECID) decided to restore every traditional library within the ksar, the actual places where the ancient manuscripts have been kept for generations. Terrachidia NGO has spearheaded the Libraries Preservation Project, using traditional building techniques and local materials and labour to carry out these restorations.
\end{abstract}

El antiguo ksar de Chinguetti fue declarado Patrimonio de la Humanidad por la UNESCO en 1996. Se encuentra en África Occidental, en una de las rutas comerciales de caravanas más importantes, en funcionamiento desde el siglo VIII hasta principios del siglo XX. El tráfico transahariano -principalmente basado en productos como la sal, el oro y el marfil- también fomentaba el desarrollo cultural a lo largo de la ruta. A medida que se fueron estableciendo contactos comerciales, culturales y religiosos a lo largo de los siglos, constantemente se escribían, copiaban, transportaban, compraban y vendían manuscritos. Tras un intento fallido de construir un museo que albergase los manuscritos más importantes de Chinguetti en el año 2000, la Agencia Española de Cooperación al Desarrollo (AECID) decidió restaurar todas las bibliotecas tradicionales del $k s a r$, los lugares en que realmente se han mantenido los antiguos manuscritos durante generaciones. La ONG Terrachidia ha liderado el Proyecto de Preservación de las Bibliotecas y ha recurrido a técnicas de construcción tradicional y a materiales y mano de obra locales para llevar a cabo estas restauraciones.

O antigo ksar de Chinguetti foi nomeado Património Mundial da UNESCO em 1996. Está localizado na África Ocidental, numa das mais importantes rotas comerciais de caravanas, funcional desde o século VIII até ao início do século XX. O tráfego transaariano - baseado principalmente em produtos como o sal, ouro e marfim - também fomentou o desenvolvimento cultural ao longo da rota. Com o estabelecimento de contactos comerciais, culturais e religiosos ao longo dos séculos, manuscritos foram continuamente escritos, copiados, transportados, comprados e vendidos. Na sequência de uma tentativa falhada de construir um museu para albergar os manuscritos mais importantes de Chinguetti em 2000, a Agência Espanhola de Cooperação Internacional para o Desenvolvimento (AECID) decidiu restaurar todas as bibliotecas tradicionais do ksar, os locais reais onde os antigos manuscritos foram guardados ao longo de gerações. A ONG Terrachidia liderou o Projecto de Preservação das Bibliotecas, utilizando técnicas de construção tradicionais e materiais e mão-de-obra locais para levar a cabo estas restaurações.

$<$ Tower of the old mosque of Chinguetti (Carmen Moreno) 


\section{Introduction}

The Municipality of Chinguetti and other national and international institutions agreed in 2000 to build a new space to collect all the town's ancient manuscripts and ensure their preservation for future generations. In response to the increasing international interest in the manuscripts and in the traditional architecture and urban structure of the place, the building was envisioned as a museum, open to tourism. The building project involved restoring an old house in the ksar (the old quarter of the settlement) and adding new spaces around its courtyard, respecting the shape, volumes, and materials of the traditional Chinguettian houses. Unfortunately, the local families who possess the manuscripts were never involved in the project, so no manuscripts were ever held or exhibited there. Despite the impressive new building, they decided not to give up their heirlooms; instead, they kept their manuscripts at home, as they had always done. It is usually said that architecture cannot survive without a function, and the UNESCO Building, as it is known by the local residents, is now in a very bad condition. It would need a thorough renovation before it can be used.

The Spanish Agency for International Development Cooperation (AECID) has been working in Mauritania for several years. They decided to take on the problem of preserving this heritage in conjunction with the Municipality of Chinguetti and the association of manuscript-owning families, which represents a total of twelve family-owned libraries. It was decided that the best option to solve the problem would be to restore every room or space in the houses where the manuscripts are kept. This way most of the families were involved in the project, which required less funding than other more ambitious initiatives.

Terrachidia NGO was invited to join the project because of its experience in Saharan vernacular architecture and its knowledge of traditional building techniques and materials.

Remote rural settlements in Africa are fragile places with very few surrounding resources, and obsolete infrastructures complicate any delivery of construction materials. These are both crucial factors to the success of any project in the area. Terrachidia is therefore committed to using local labour whenever possible in order to promote local economic development.

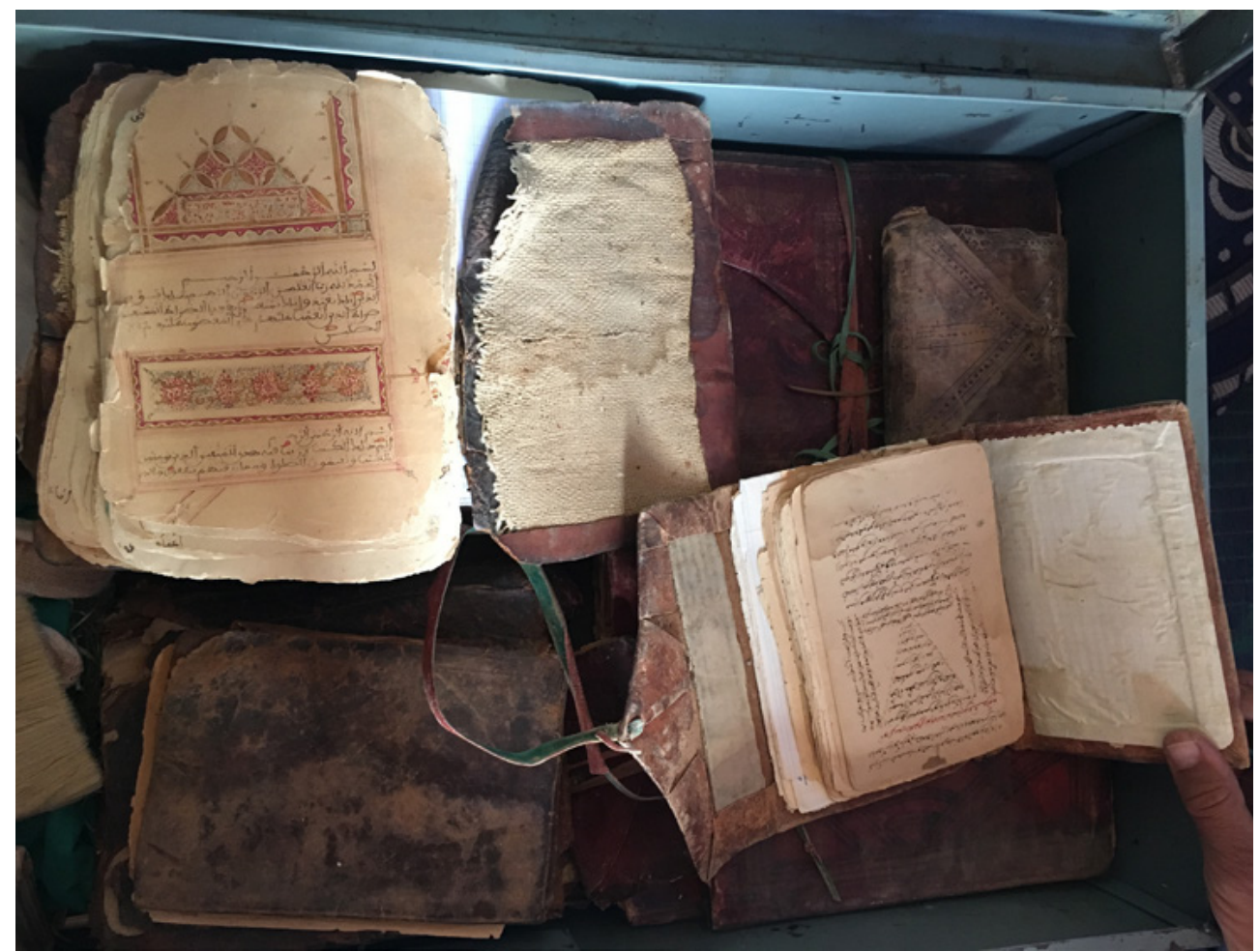




\section{Historical context}

According to oral tradition, the settlement of Abweir was founded in 777 A.D. near what is currently Chinguetti. A second town was founded in the thirteenth century, the ruins of which can still be found under the dunes southwest of the town. The settlement was also part of the Almoravid Empire and became prosperous during the thirteenth century and, above all, after the eighteenth century.

The first written evidence of the town's existence dates from the sixteenth century, when Valentim Fernandes described Chinguetti as the third most important settlement in Mauritania. Chinguetti also lent its name to the country for centuries, which was known as Shinqit Bilad, "the country of Chinguetti”.

Chinguetti is located on one of the most important trade routes in West Africa, known as Trig allamtuni, which links southern Morocco to Sudan (as the area located to the south of the Sahara was historically known). This route became the main access point to gold and other products from Sudan. The salt mines of Idjil were the other source of Chinguetti's prosperity, as salt was used as currency in trade exchanges. Sudanese commerce through the Sahara ebbed with the prosperity of transatlantic commerce, which caused an economic decline in Mauritania.

After the great drought of the 1970s, Chinguetti was almost completely depopulated, with only around 400 residents remaining. Residents started to return in the last decade of the twentieth century as the drought began to subside, but the town has never recovered the splendour of the past.

Nowadays Chinguetti is a small town of 4,800 residents with a rural economy. Trading opportunities are hampered by the difficulty and cost of travelling by road, and a lack of resources for improving agricultural has reduced its economy to subsistence levels.

In recent years, tourism has become an important economic driver for the city, as people have come to know more about the so-called "Sorbonne of the desert". The close relationship between both sides of the desert and Europe left a significant mark on this area, and the best testimony of this is still its ancient manuscripts.

\section{Trade caravans}

The last caravan of dromedaries left Chinguetti in the middle of the last century. It came from Guinea and headed towards the Drâa Valley oases, such as M'hamid el Ghezlane and Tagounite. Trade routes of this kind had been connecting far-off cities like Cairo, Mecca and Marrakech for centuries.

Caravans usually started their journeys in wintertime and could include thousands of dromedaries carrying goods such as ivory, salt, spices, ostrich feathers, sugar, grains, purple dye, gold, and slaves. Some desert cities along the routes became hubs of knowledge and cultural exchange. They also became homes to mahadir, desert schools for studying religion and spiritual arts. Manuscripts were an important part of this Saharan traffic. They contained information about very different fields, including botany, medicine, astrology and religion, especially the Koran.

Manuscripts were produced and reproduced by hand in Arabic, and some of them also included decorative handwritings and drawings. 


\section{The town of Chinguetti and its architecture}

Chinguetti was named a UNESCO World Heritage Site in 1996. It is one of four heritage cities in Mauritania, the others being Ouadane, Tichit and Walatah.

The four cities have been built in a logical manner, using local natural resources to adapt the desert landscape to people's needs and to transform it into a habitable place.

The main urban structure of the region's human settlements was determined by the oases. In the past, most of the population was nomadic. This continues to be a way of life for many people today, especially seasonal farmworkers. Oases gave shelter to many inhabitants, who set off to build their villages and houses in the middle of the desert. They also made life possible, despite the extreme weather conditions, with temperatures rising to over $50^{\circ} \mathrm{C}$ in summer and dropping to $0^{\circ} \mathrm{C}$ in winter nights. Furthermore, rain is rare and sandstorms are common. Indeed, the water table of the seasonal Batha river, which irrigates Chinguetti's fields, is progressively declining, causing a loss of farmland and encroaching dunes on houses in the southern areas of the old town.

Chinguetti is not only an important commercial settlement, but also a significant religious site for Islam. The city is organized around the mosque, with the rest of the buildings arranged concentrically.

The fact that people settled in villages did not mean that they ceased to be nomadic. Indeed, houses remain empty for most of the year, and one of their main functions is to house family assets, including manuscripts.

The local architecture also reveals the people's nomadic character. The haima, the traditional tent of the nomads, is intrinsic to the town. These tents are used throughout the region in places like Chinguetti which have enjoyed long periods of peace, in contrast to places with more defensive structures, such as the neighbouring Ouadane.

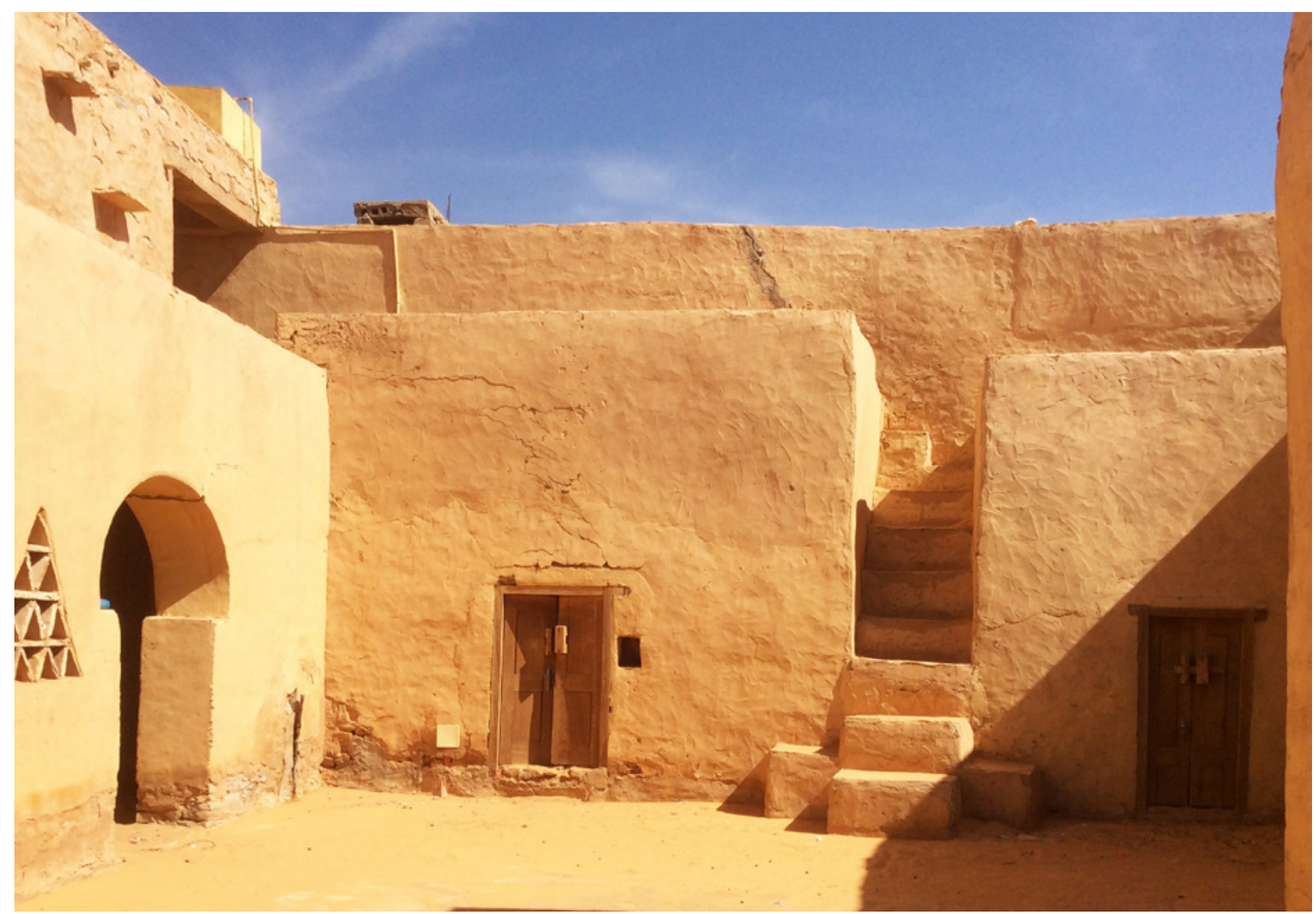


Interior of the Hamoni Library (Carmen Moreno)

1: Courtyard of the Wanane Library (Carmen Moreno)

2: Courtyard of the Hamoni Library (Raquel Peña)

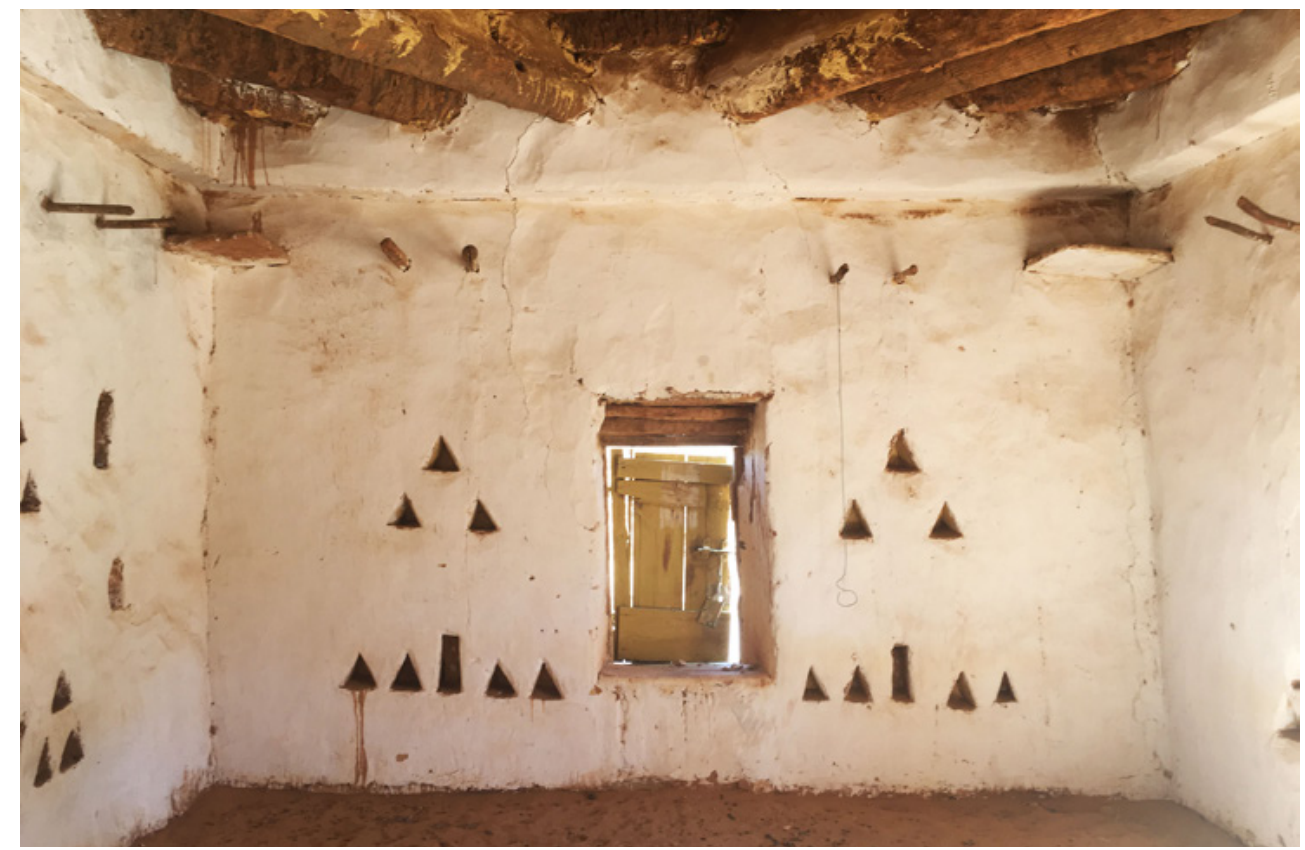

The ancient libraries

The establishment of libraries in Chinguetti is strongly linked to the Saharan trading routes. They were roads for trade and pilgrimage, but also for the exchange of knowledge. Ancient libraries have been home to manuscripts for generations, and families have kept their heirlooms in their houses to ensure that they are preserved and kept safe. Their leather covers were made by hand. They are protected in large chests that were moved outside during the hot season to dry out the humidity accumulated during the wet season.

Large Arab families preserve their heirlooms as a way to reinforce their family identity and their link with the history of Chinguetti.

The most important libraries in terms of the number of manuscripts are Habott, Hamoni and Wanane. Other families, like Mahmud, also have a long tradition of manuscript preservation but have not participated in this restoration project.

Similar libraries can be found in other cities in Mauritania, such as Ouadane, and in other countries such as Mali or Niger.
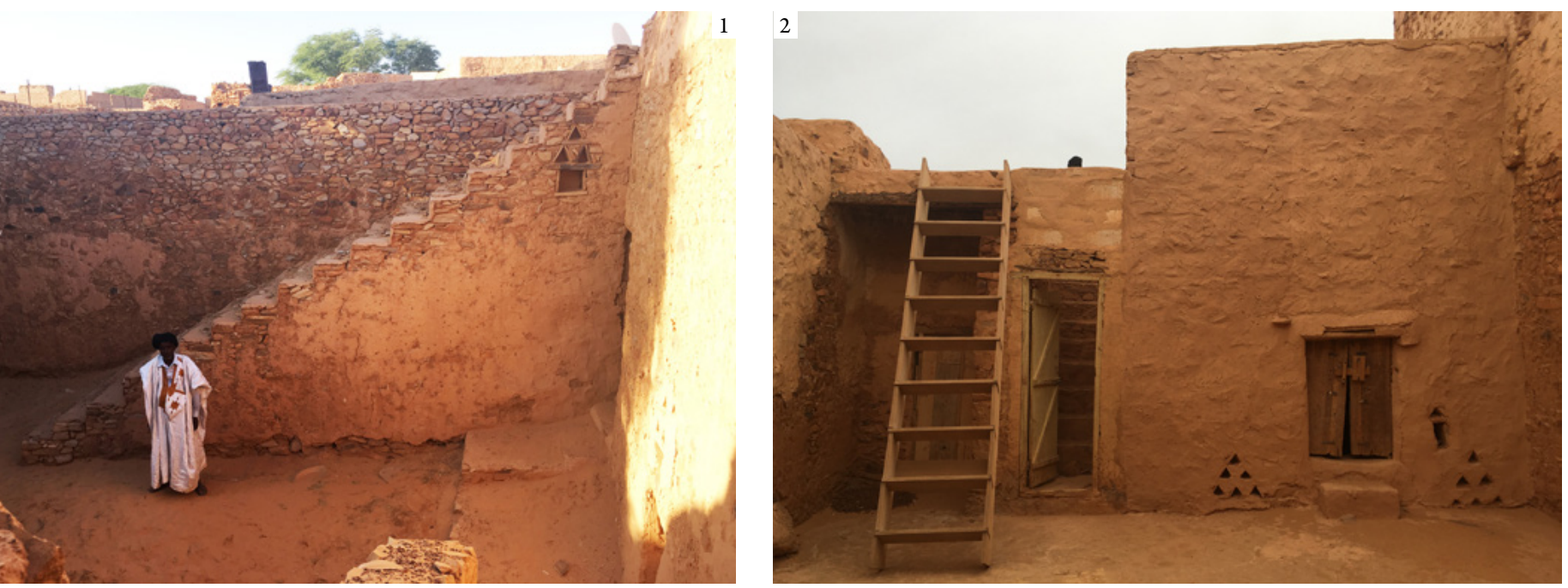


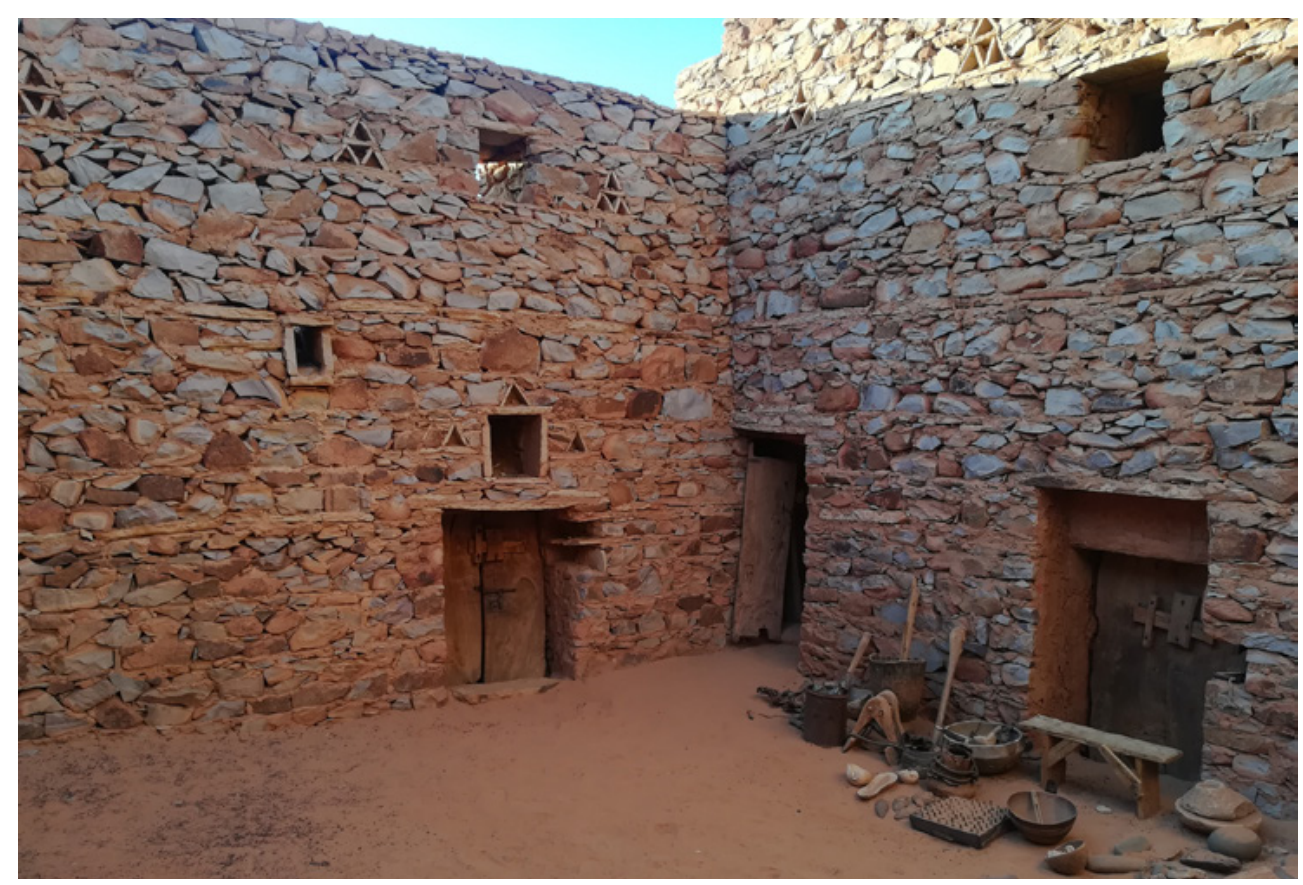

\section{Traditional building techniques}

Traditional crafts and building techniques are linked to the desert and to the nomadic way of life. Each tribe had its own craftsmen, called m'aalem, with the knowledge of different building techniques.

Local stone, named legré, has been used as the main construction material all around Chinguetti, even in new buildings constructed with contemporary techniques. The massive walls are quite homogenous and provide the necessary thermal and acoustic insulation, as well as thermal inertia. They are around fifty centimeters thick and are built with two stone faces and mud mortar in between. Walls are usually plastered on the inside and are rarely rendered on the façade.

Roofing is made from palm wood beams (half or quarter trunks, depending on the required thickness) carpeted over with palm leaves. The maximum distance between walls is therefore 2.50 meters, which is the maximum height of a palm tree. Acacia wood has traditionally been used as well, and nowadays some bois rouge (African mahogany) is imported from Senegal. Walls are topped with corbels, which are placed towards the inside of the building to better support the beams and reduce the distance between walls.
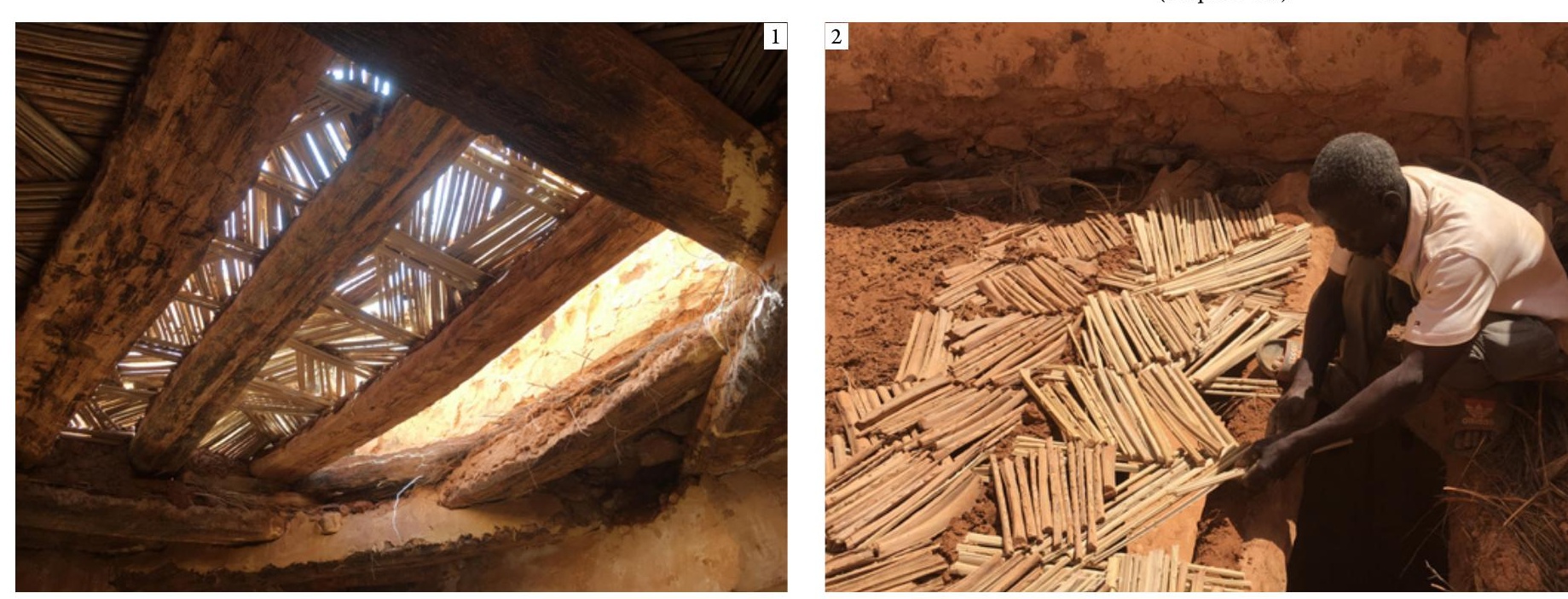

Courtyard of the Mahmoud Library with legré walls (Raquel Peña)

1: Collapsed roof

2: Roofing techniques during the restoration works

(Raquel Peña) 
1: Local craftsman working on the finishing of an exterior wall

2: Tests of several mixtures for the finishings

(Carmen Moreno)
The beams are separated from the palm leaf layer with palm leaf stalks, which also serve to strengthen the structure. Over the palm leaf layer there is an insulating layer of sbat, a kind of local straw, and on top of that, a ten centimeter layer of compressed wet mud. The final twenty centimeter layer is a drier clay mixture that creates the correct slope to direct water towards the draining scuppers made from palm wood. Roof edges do not have eaves and are instead covered in a rich clay mortar.

Joinery is made from palm or acacia wood, and small wooden sticks are hammered into the interior walls to be used as hangers for tools and clothes. At present, the joinery of all façades and patios is painted in blue and green tones.

Floors are made from a compressed mixture of clay and gravel, sometimes with a layer of sand on top. In some houses a sort of elevated floor is found. It allows a space to be heated by placing burned embers underneath. The Ahel Loudaa library also uses this traditional heating system.

The best-known decorative details are the niches and triangular apertures built into the façade walls that open onto interior courtyards or the insides of homes. These simple geometric forms are made from stone and sometimes rendered with mud. The Hamoni library has some good examples of these details.

Clay has always been used in the traditional architecture of Chinguetti. However, extracting it from quarries is a difficult process. Men must descend over seven metres to extract it by hand, breaking the clay rocks with a pick and lifting them out with a pulley. Clay is used for roofing and for the façade and interior renderings, though lime mortar and lime paint have traditionally been used as well.

Lack of maintenance is the main threat to heritage structures. In recent decades, social and economic changes have caused them to be abandoned and fall into disuse. One of the most alarming threats to Chinguettian heritage is xylophages, or termites, which climb up from the ground into floors and roofs and seriously damage their wooden structures. However, in recent times there has been a greater awareness of this heritage, of its fragility, and of the need to preserve it.
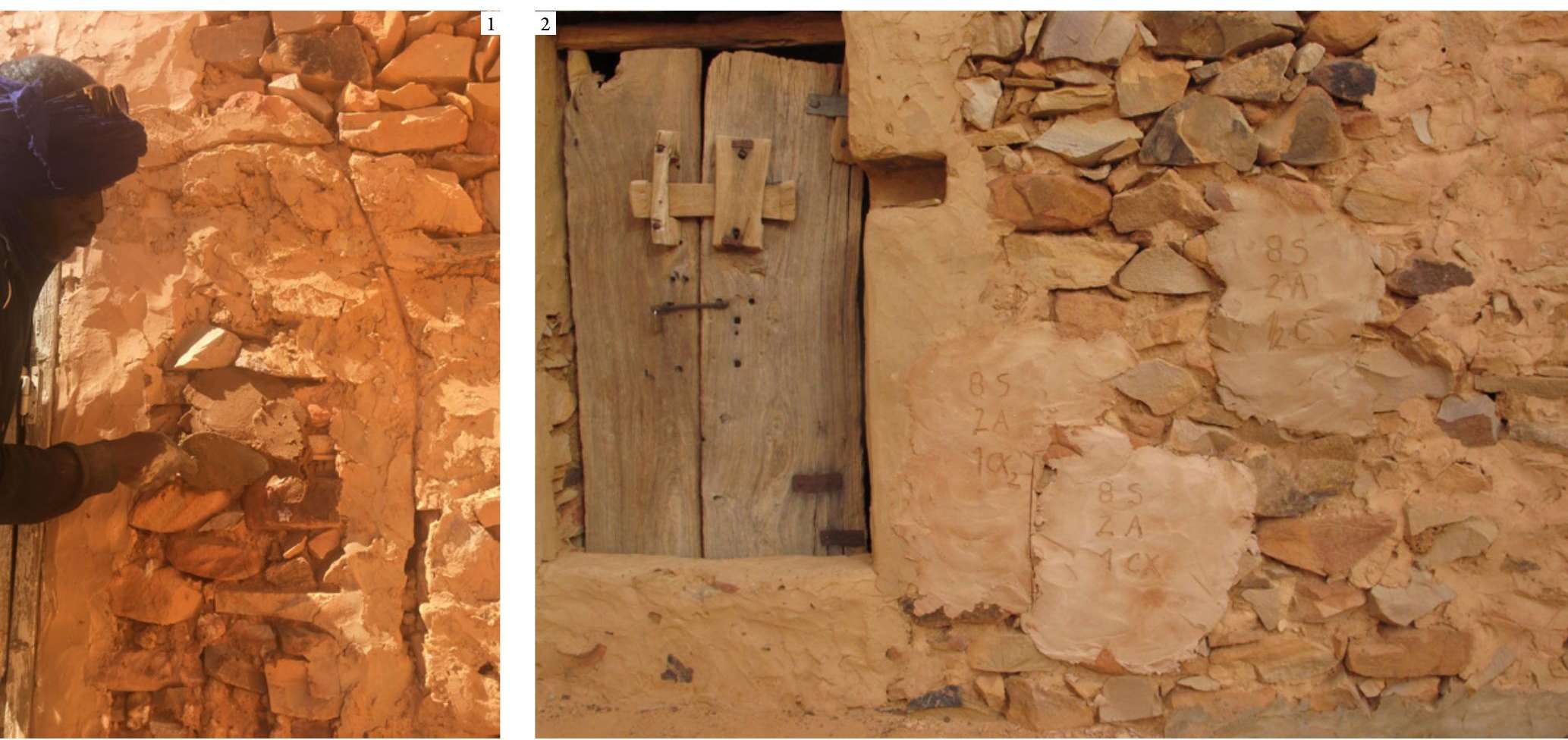


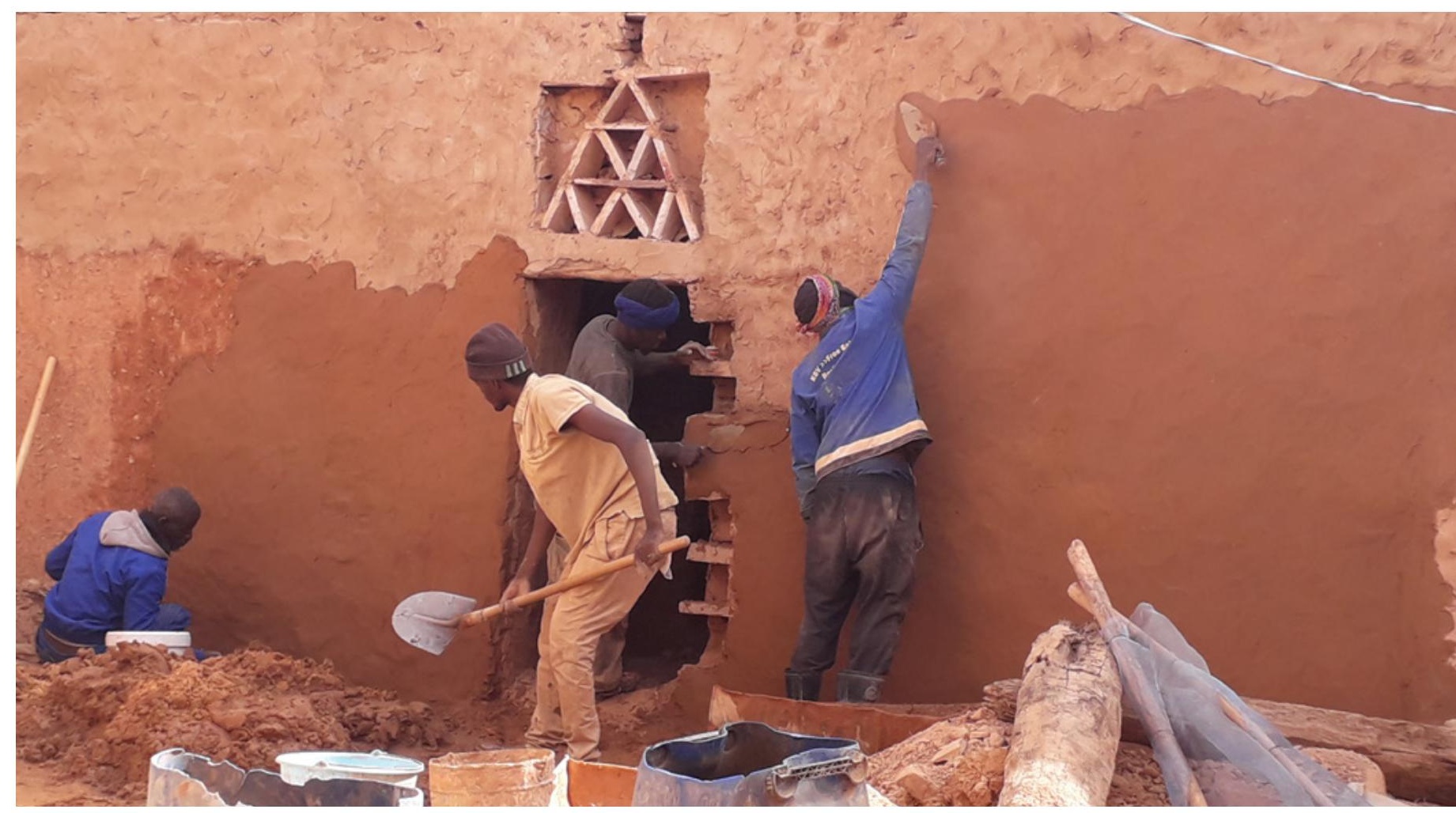

\section{The restoration project}

Restoration works in one of the libraries (Raquel Peña)

As a UNESCO World Heritage site, the aim of the project was to preserve the original conditions of each space by repairing damaged elements and replacing ruined ones. Terrachidia defined a four-phase project schedule in order to study and understand the place, its architecture, and the current condition of its manuscripts:

Phase 1: Dedicated to visiting every library participating in the project, recording works, doing research and testing local materials (wood beams, mud renderings, etc.).

Phase 2: Hands-on workshop with local labourers to encourage them to return to the use of local materials and techniques. It included testing several rendering mixtures with different proportions of sand, clay, lime and cement, as well as the use of lime painting and the techniques using palm tree leaves.

Phase 3: Restoration works with a team of local craftsmen, practicing traditional construction techniques, including those needed for roof waterproofing and the finishings.

Phase 4: Supervision of the finished works to ensure they were correctly executed.

The most common problems found in the libraries were:

Significant damage to the upper part of the walls was observed, with wide cracks which allowed water to leakin and wash out the mud mortars within the stone masonry walls. This water weakened the interlocking of the three-leaf wall, causing inner cracking and the separation of the outer faces of the wall at the top-zone. This process is usually followed by the buckling of the separated parts and the eventual collapse of the entire structure. Apart from that, we found corners that were poorly interlocked, causing vertical cracks. Other problems were: cement-based rendering and plastering of façades and interiors; washing of mud renders, due to lack of maintenance; damaged mud plasters; damaged or collapsed walls; cracked waterproof layer in rooftops; damaged joints between the draining scuppers and clay layer; damaged palm wood beams because of termites; and damage to roofs and other wooden structures. 

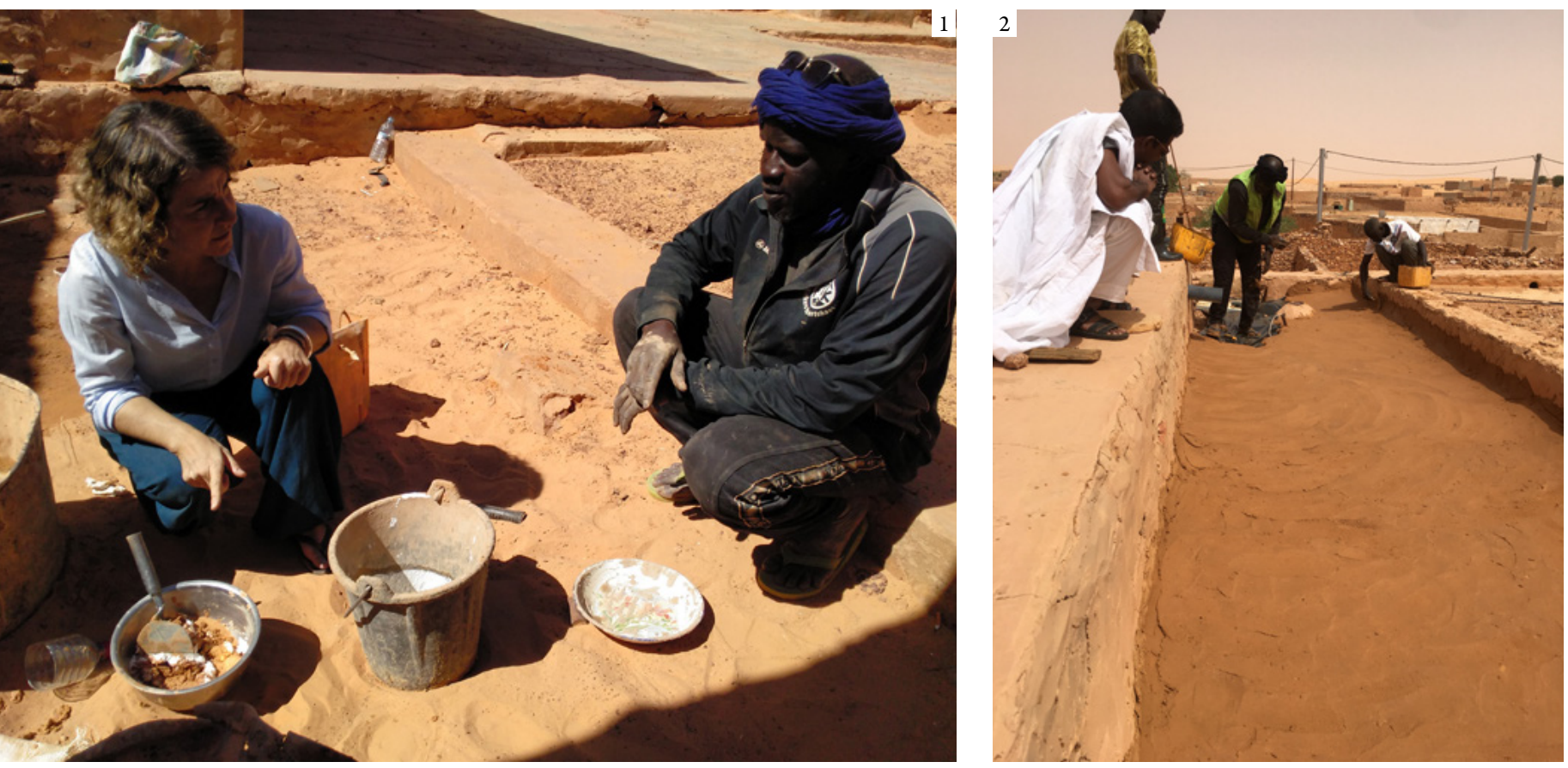

1: Hands-on workshop with local labourers (Ana María Sánchez Salcedo)

Incorporating cement into traditional buildings is a practice which has spread throughout the world. However, it is not always used correctly, and its physical and chemical behaviour is often unsuited to vernacular architecture, where traditional materials are more elastic and sensitive to humidity and thermal changes. The use of cement renderings on façades hampers the capillary action of humidity from the interior of the stone walls, leading to cracks and leaving bare walls behind. Access to some materials may have become difficult in some places, especially in remote rural locations, but obtaining and using them is worth the effort.

To avoid these problems, Terrachidia suggested increasing the proportion of clay in render mixtures and avoiding the use of cement. There was wide-spread use of renders with a high percentage of cement (up to 30\%) and just a 5\% of clay to colour the mixture. Adding more clay and a small proportion of lime to the mixture achieves the natural colour while optimising the quality of the renders. In the end, the optimum proportion, using only locally available materials, was found to be: $75 \%$ sand, $20 \%$ clay and $5 \%$ lime.

Roof waterproofing was improved by adding reused car oil to the mixture used for the first layer of mud. This first layer was still covered with a polyethylene sheet, as is frequently done nowadays. This was followed by a second layer of mud, and then an additional layer with a high percentage of sand in the mixture was added as a finishing layer to protect the clay from erosion and thermal changes. Stabilized mortar with some cement was used for the junctions of the roofs with the top of the walls.

\section{Conclusion}

This intervention to contribute to the preservation of this UNESCO World Heritage site was an example of good professional practice based on local resources and skills and could become a model for many other anonymous heritage sites.

By preserving people's houses and improving their living conditions, we also preserve the heritage which they keep alive.

Interventions in heritage sites should always be carried out in partnership with the local community and the local administration, as well as with any other cultural institutions which could contribute to the project's success. Traditional materials should always be used. They 
should also be improved when possible, but relying on local resources. New materials should only be incorporated if there are no other local traditional options available and providing they do not disturb the essence of the architecture and are consistent with how it is constructed. These principles should be followed in order to preserve the character of this kind of cultural heritage, which is deeply linked to the identity of the local people.

\section{Bibliography $\mid$ Bibliografía | Bibliografia}

Corral Jam, José. 2000. Ciudades de las Caravanas. Itinerarios de Arquitectura Antigua en Mauritania. 1978-1981. Granada: Fundación El Legado Andalusí.

Du Puigaudeau, Odette; and Sénones, Marion. 2000. Mémoire du Pays Maure (1934-1960). Paris: Ibis Press.

Du Puigaudeau, Odette. 2002. Arts et coutumes des Maures. Paris: Ibis Press.

Fall, Abdallahi; Cormillot, André; and Ould Beyrouk, Adnan Mohamed. 2004. L'Adrar. Les villes anciennes, Chinguetti, Ouadane et Le Guelib er Richât, vol. 2. Paris: Éditions SÉPIA

Gaudio, Attilio. 2002. Les bibliothèques du désert. Recherches et études sur un millénaire d'écrits. Paris: Harmattan.

Giacomello, Alessandro; and Pesaro, Alessandro. 2009. Sauvegarde des bibliothèques du désert. Matériaux didactiques. Pasian di Prato: Litho Stampa.

Krätli, Graziano. 2004. The Book and the Sand: Restoring and Preserving the Ancient Desert Libraries of Mauritania. Part 1. World Libraries, 14, 1, 21-44.

Le Quellec, Jean-Loïc. 2009. Art rupestre, Patrimoine archéologique et industrie pétrolière au Sahara. In: Société des amis du Musée national de préhistoire et de la recherche archéologique (Ed.), L'art pariétal, conservation, mise en valeur, communication, 23-28. Les Eyzies: Société des amis du Musée national de préhistoire et de la recherche archéologique.

Mauny, Raymond. 1955. Notes d'histoire et d'archéologie sur Azougui, Chinguetti et Ouadane. Bulletin de l'Institut français d'Afrique noire. Série B, Sciences humaines, 17 (1-2), 142-162.

Monod, Théodore; and Zanda, Brigitte. 1992. Le Fer de Dieu. Histoire de la météorite de Chinguetti. Arlés: Actes Sud.

Monod, Théodore. 1995. Maxence au désert: souvenirs de la Mauritanie. Arlés: Actes Sud.

Páez López, Jerónimo (coord.). 2003. Mauritania y España. Una historia común: los Almorávides. Unificadores del Magreb y Al-Andalus (S.XI-XII). Granada: Fundación El Legado Andalusí.

Terrachidia. 2019. Chinguetti, el legado del desierto. Madrid: Agencia Española de Cooperación Internacional para el Desarrollo.

Restoration works in one of the libraries (Raquel Peña) 


\section{Biographies $\mid$ Biografías $\mid$ Biografias}

\section{Carmen Moreno Adán}

She is an Architect and holds a Master's in Conservation and Restoration of Architectural Heritage and a Postgraduate Diploma in Development of Precarious Human Settlements from the Universidad Politécnica de Madrid. She is an Associate Professor at the Department of Architectural Composition of the Universidad Alfonso Xel Sabio, Madrid. She has been a guest lecturer at various conferences and dedicates her professional activity to the recovery and restoration of public spaces and buildings within traditional towns. She is a member of the management committee at the LabOasis Foundation and a member of the board of Terrachidia NGO

\section{Raquel Peña López}

She is an Architect and holds a Postgraduate Diploma in Development of Precarious Human Settlements from the Universidad Politécnica de Madrid and another in Design and Management of Exhibitions from the Universidad Europea de Madrid, having completed her postgraduate studies in the Department of Architecture and Construction at the United Nations branch in New York. She has been linked for more than ten years to the Architects without Borders NGO through the development of cooperation projects and is a member of the board of Terrachidia NGO.

\section{Oriol Domínguez Martínez}

$\mathrm{He}$ is an Architect and holds a Master's in Conservation and Restoration of Architectural Heritage, a Postgraduate Diploma in Development of Precarious Human Settlements from the Universidad Politécnica de Madrid, and a Master's in Structural Analysis of Monuments and Historical Buildings from the Università di Padova and the Universidade do Minho. He has extensive professional experience in Europe, North America, South America and Africa. He is a member of the board of Terrachidia NGO and is strongly linked to academia, with teaching experience in Spanish universities and having lectured in several national and international institutions. In recent years he has been working as Quality Assurance Coordinator for the stone masonry works of the Sagrada Familia Basílica, in Barcelona. 